\title{
Microwave-enhanced gasification of sewage sludge waste
}

\author{
Young Nam Chun ${ }^{\dagger}$, Hee Gaen Song \\ Department of Environmental Engineering, Chosun University, Gwangju 61452, Republic of Korea
}

\begin{abstract}
To convert sewage sludge to energy, drying-gasification characteristics during microwave heating were studied. During the gasification of carbon dioxide, the main products were gas, followed by char, and tar in terms of the amount. The main components of the producer gas were carbon monoxide and hydrogen including a small amount of methane and light hydrocarbons. They showed a sufficient heating value as a fuel. The generated tar is gravimetric tar, which is total tar. As light tars, benzene (light aromatic tar) was a major light tar. Naphthalene, anthracene, and pyrene (light polycyclic aromatic hydrocarbon tars) were also generated, but in relatively small amounts. Ammonia and hydrogen cyanide (precursor for $\mathrm{NO}_{\mathrm{x}}$ ) were generated from thermal decomposition of tar containing protein and nitrogen in sewage sludge. In the case of sludge char, its average pore diameter was small, but specific area, pore volume, and adsorption amounts were relatively large, resulting in superior adsorption characteristics.
\end{abstract}

Keywords: $\mathrm{CO}_{2}$ gasification, Microwave heating, Producer gas, Sewage sludge, Sludge char

\section{Introduction}

Along with industrial developments and the rising standard of living, the demand for energy is increasing more than ever. Most energy needs are met by fossil fuels. Due to various environmental issues, however, such as greenhouse gas emissions and limited fossil fuel resources, there is a rising interest in developing new alternative energies.

Biomass is an environmentally friendly renewable energy that can implement carbon neutrality. In particular, sewage sludge waste continues to be discharged more and more from wastewater treatment plants and is difficult to treat. This sewage sludge waste is a biomass that can be converted to clean energy resources.

Among the conversion technologies for biomass wastes, thermochemical conversion such as pyrolysis or gasification of sewage sludge are currently attracting attention and have been studied. These methods can produce energy with biogas, bio-oil, sludge char, etc. [1-4]. Gasification applies a conventional heating method based on external heat sources by convective, conductive, and radiative heat transfers. However, the conventional heating method requires a huge amount of heating energy for

This is an Open Access article distributed under the terms of the Creative Commons Attribution Non-Commercial License (http://creativecommons.org/licenses/by-nc/3.0/) which permits unrestricted non-commercial use, distribution, and reproduction in any medium, provided the original work is properly cited.

Copyright (C) 2019 Korean Society of Environmental Engineers gasification because bio-cells have surface water and bound water in the sludge.

Researchers are now interested in a thermal conversion treatment of biomass by the microwave (MW) heating method as an alternative to the conventional heating method [5-7]. MW heating is applied to the sludge so that MWs can go directly into bio-cells to vibrate molecules and atoms in the bio-cells and generate heat unlike conventional heating by conduction of external hot air [8]. Therefore, heating efficiency and heating rate are higher than in conventional heating, contributing to reduced heating time.

However, the nitrogen component in sludge forms harmful ammonia $\left(\mathrm{NH}_{3}\right)$ and hydrogen cyanide $(\mathrm{HCN})$ precursors during conversion to biofuel by MW-based thermal decomposition [9]. Components in bio-producer gas are converted to nitrogen oxide, $\mathrm{NO}_{\mathrm{x}}$, in combustion, and this can be involved in photochemical reactions or cause acid rain [10]. Many studies have been carried out about nitrogen oxide produced from the combustion of fossil fuels like coal [11]. However, given that the conversion mechanism for gasification of nitrogen components in sludge is very different, it is necessary to examine behaviors thereof.

The conventional method to convert sewage sludge to energy involves drying, pyrolysis or gasification of dewatered sludge after
Received September 10, 2018 Accepted December 1, 2018

${ }^{\dagger}$ Corresponding author

Email: ynchun@chosun.ac.kr

Tel: +82-62-230-7156

ORCID: 0000-0002-7617-7705 
mechanical processing in a wastewater treatment plant. Meanwhile, a large amount of energy is consumed along with odor. In addition, the pyrolysis or gasification process is performed after the drying process, which requires extra equipment and costs [12]. Therefore, if drying-gasification can be while dewatering sewage sludge with high moisture content, it can alleviate the issues listed above. In addition, utilization of $\mathrm{CO}_{2}$ separated from Carbon Capture Storage for gasification gas can solve environmental contamination issues and reduce cost during the transportation and storage process.

In this study, a new type of MW-based thermochemical treatment technology was developed for sewage sludge wastes. For this purpose, energy conversion characteristics in a sequential drying-gasification process of dewatered sludge using MW dielectric heating were analyzed. Experiments were performed to know the effects of $\mathrm{CO}_{2}$ gasification according to different gas temperatures and catalyst impinged-char, giving products such as gas, tar, and char.

\section{Materials and Experimental Methods}

\subsection{Sewage Sludge Sample}

The sewage sludge used in this study was physically centrifugal-dried and from the municipal wastewater treatment plant. Proximate analysis and ultimate analysis of the dewatered sewage sludge were shown with inorganic compounds in Table 1. The sludge contained $82 \%$ of moisture, and was used to analyze MW heating characteristics for which drying-gasification were carried out at the same time without the hot air drying process.

For inorganic elemental analysis of a sewage sludge, the ICP spectrometer (Agilent Technologies, 720 I CP-OES) was used to measure the components of $\mathrm{Cd}$, Co, chrome $(\mathrm{Cr})$, copper $(\mathrm{Cu})$, iron ( $\mathrm{Fe}$ ), $\mathrm{Hg}$, manganese (Mn), Ni, $\mathrm{Pb}$, and $\mathrm{Zn}$. For inorganic oxidant analysis, the X-ray fluorescence Spectrometer (Shimadzu, ED-720) was used to measure $\mathrm{Fe}$, $\mathrm{Cr}$, nickel (Ni), and $\mathrm{Mn}$.

\subsection{Experimental Apparatus}

To examine drying-gasification characteristics by MW heating of dewatered sludge, a lab-scale instrument was built. The test apparatus was composed of a specially designed MW gasifier, a gas feed line, a gas/tar sampling-analysis line, and a nitrogenous compound gas (NCG) sampling train.

The MW gasifier includes a quartz tube reactor $(40 \mathrm{~mm}$ in diameter, $320 \mathrm{~mm}$ in length) vertically installed in the $2 \mathrm{~kW}$-multimode-MW cavity chamber. A fixed bed reactor (FBR) was designed to move a sludge sampling basket upward and downward. During each experiment, the sludge sample was easily introduced and discharged into/from the FBR. The sample temperature in the FBR was measured by an inserted thermocouple (k-type, $2 \mathrm{~mm}$ in diameter) and continuously monitored with a data logger (Model Hydra data logger 2625A, Fluke, USA). The temperature in the FBR could be set up to $1,000^{\circ} \mathrm{C}$ by the connected controller to the thermocouple to enable minute control.

The gas feed line was composed of a $\mathrm{CO}_{2}$ cylinder (gasification gas), an argon cylinder (purge gas), MFCs $\left(\mathrm{CO}_{2}\right.$ : BRONKHORST, F201AC-FAC-22-V, Netherlands, Ar: Line Tech, M3030V R, Korea) and a multichannel controller (iCDS, LtD., FM-30VE R, Korea) for MFC flow control, respectively.

The gas/tar sampling-analysis line was composed of a collection line for tar and produced gas in $\mathrm{CO}_{2}$ gasification and analysis equipment. The collection line was composed of impingers in an isothermal bath $\left(15^{\circ} \mathrm{C}\right)$ and ice bath $\left(-20^{\circ} \mathrm{C}\right)$ controlled by a chiller (ECS-30SS, Eyela Co., Japan) and a wet-type gas meter (W-NK-1A, Shinagawa, Japan). The analysis line was composed of a GC-FID for analyzing light tar (GC-14B, Shimadzu, Japan), a rotary evaporator (Model N-1000-SW, Eyela, Japan) for gravimetric tar, and a GC-TCD for analyzing gas (CP-4900, Varian, Netherland). Produced gas was captured along with wet tar sampling, and GC was protected from tar generated in sampling by an activated carbon filter and a cotton filter. $\mathrm{H}_{2}$, CO, methane $\left(\mathrm{CH}_{4}\right), \mathrm{O}_{2}$, and $\mathrm{N}_{2}$ were analyzed using the Molecularsieve-5A column, and $\mathrm{CO}_{2}, \mathrm{C}_{2} \mathrm{H}_{4}, \mathrm{C}_{2} \mathrm{H}_{6}$, and $\mathrm{C}_{3} \mathrm{H}_{8}$ were analyzed using the PoraPlot-Q column for simultaneous analysis.

The NCG sampling train consisted of three impingers arranged in series to absorb $\mathrm{NH}_{3}$ and $\mathrm{HCN}$. The first was connected in a reverse orientation to prevent reverse flow, and the others were placed for adsorbing the nitrogenous compounds.

Table 1. Chemical Characteristics of the Sewage Sludge

\begin{tabular}{|c|c|c|c|c|c|c|c|c|c|}
\hline \multicolumn{4}{|c|}{ Proximate analysis (wt\%) } & \multicolumn{6}{|c|}{ Ultimate analysis ${ }^{\mathrm{a}, \mathrm{b}}$ (wt\%) } \\
\hline $\mathbf{M}$ & $A^{a}$ & $\mathbf{V M}^{\mathrm{a}}$ & FC $^{\mathbf{a}}$ & $\mathrm{C}$ & $\mathbf{H}$ & $\mathbf{N}$ & $\mathbf{S}$ & $\mathbf{O}$ & $\mathrm{HHV}^{\mathrm{a}}(\mathrm{MJ} / \mathrm{kg})$ \\
\hline 82.0 & 31.9 & 62.1 & 6.0 & 44.5 & 8.3 & 6.5 & 1.8 & 38.9 & 13.6 \\
\hline
\end{tabular}

M: moisture, A: ash, VM: volatile matter, FC: fixed carbon

${ }^{\mathrm{a}}$ Dry basis, ${ }^{\mathrm{b}}$ Ash free basis

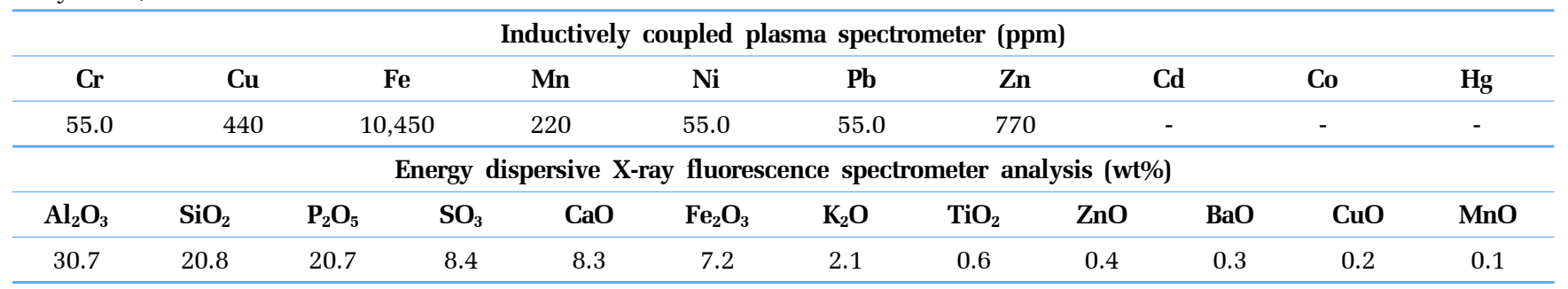




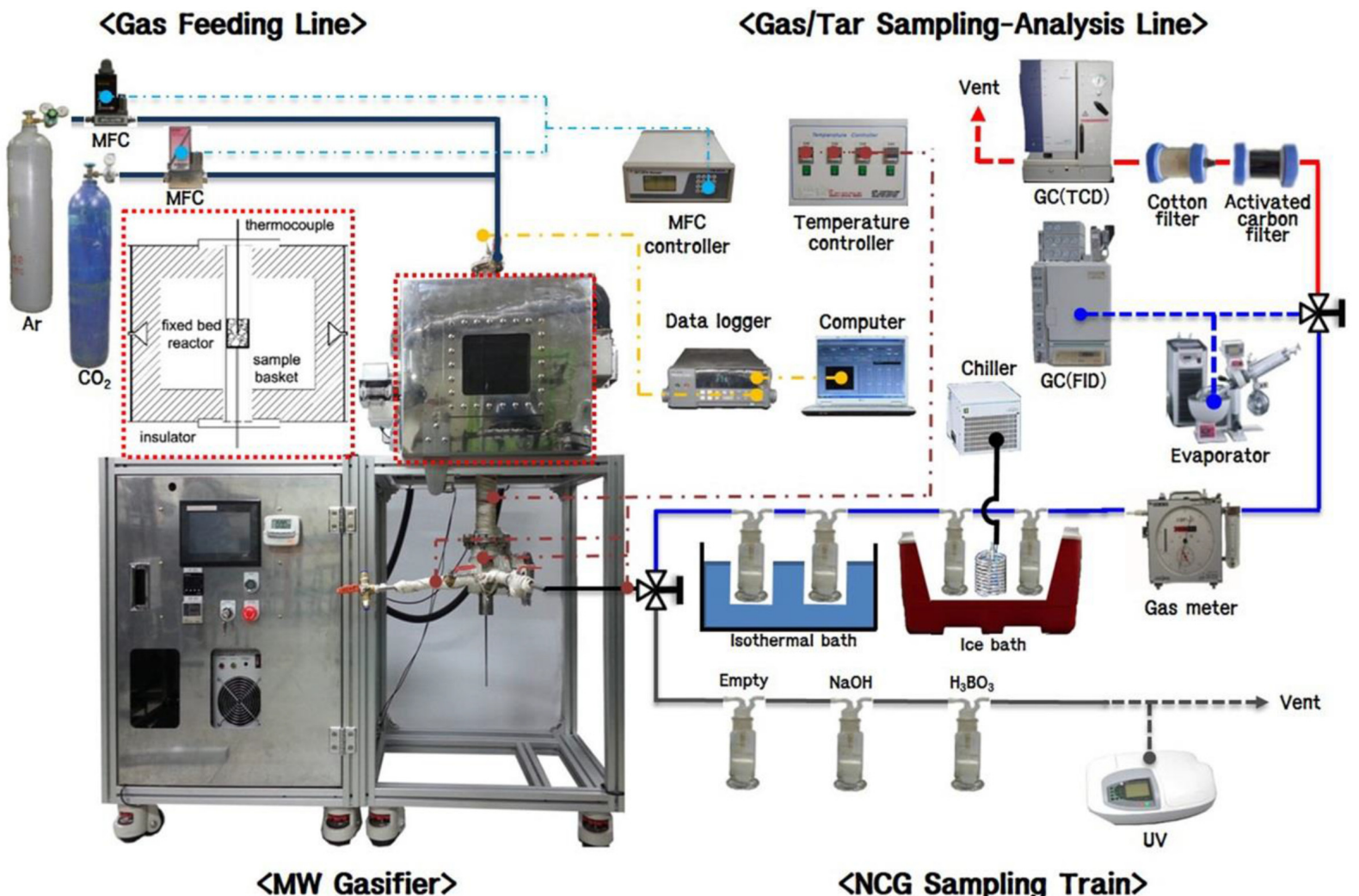

Fig. 1. MW-based gasification experiment equipment for the sewage sludge.

\subsection{Gasification Experiment}

The sludge sample was made by mixing $10 \mathrm{~g}$ of dewatered sludge with $5 \mathrm{~g}$ of sludge char as a MW receptor. The sludge char used as an MW receptor sludge char carbonized material (SCCM) was a product in the MW-based gasification process in this experiment.

For the gasification experiment, the $\mathrm{CO}_{2}$ flow rate of $1 \mathrm{~L} / \mathrm{min}$ was applied to make $\mathrm{CO}_{2}$ as a gasification gas flow through the sludge sample in the FBR. The temperature in the sludge sample was linearly raised from room temperature and maintained at the set reference temperature $\left(800^{\circ} \mathrm{C}\right)$ with $1 \mathrm{~kW}$ of power. While starting the experiment, tar was collected in an adsorption bottle for analysis and produced gas was captured in a Tedlar bag for 30 min. The tar and produced gas were then analyzed by each method. The sludge char was left until the reactor temperature reached $20^{\circ} \mathrm{C}$ with continued flow of Argon (purge gas) after collecting and capturing tar and gases.

Among the gases produced in the $\mathrm{FBR}, \mathrm{H}_{2}$, carbon monoxide (CO), $\mathrm{CO}_{2}$, hydrocarbons, etc. were analyzed with the GC-TCD. Gases of $\mathrm{H}_{2}, \mathrm{CO}, \mathrm{O}_{2}$, and $\mathrm{N}_{2}$ were analyzed using the molecular sieve 5A (80/100 mesh) column, and $\mathrm{CO}_{2}, \mathrm{CH}_{4}, \mathrm{C}_{2} \mathrm{H}_{4}, \mathrm{C}_{2} \mathrm{H}_{6}, \mathrm{C}_{3} \mathrm{H}_{8}$ by using the PoraPlot-Q column.

To measure the generated tar, wet sampling and tar analysis was conducted according to the method proposed by Biomass Technology Groups [13]. Wet sampling involved collection of tar generated in the experiment, light tar analysis via the GC-FID, and gravimetric analysis to measure total tar.
The wet sampling line was composed of six impingers and two isothermal baths for condensation and absorption of the generated tar into the solvent. Isopropyl alcohol (99.9\%) was used as a solvent to fill four impingers to contain $100 \mathrm{~mL}$, respectively. Those impingers were placed in the first isothermal bath to be at $15^{\circ} \mathrm{C}$. One of two impingers was filled with $100 \mathrm{~mL}$ of isopropyl alcohol, and the other was empty. The two impingers were placed in an isothermal bath at $-20^{\circ} \mathrm{C}$.

After sampling, $100 \mathrm{~mL}$ of isopropyl alcohol and a fine brush were used to wipe out the tar remaining in the impinger wall to be included in the solvent. The whole tar solution was filtered with a paper filter (Model F-5B, Advantec Co., Japan) to separate particulate matters therein, and $5 \mathrm{~mL}$ of solution was taken out by using a vial for light tar analysis. A syringe was used to inject $1 \mu \mathrm{L}$ of solution into the GC-FID for analysis. Light tar was analyzed for benzene, naphthalene, anthracene, and pyrene, which are major aromatic compounds with 1 to 4 benzene rings and without any substituents. The column used in GC was ZB-5 (Zebron, Phenomenex, $30 \mathrm{~m}-0.53 \mathrm{~mm}$ id, $1.5 \mu \mathrm{m}$ film thickness), and the oven temperature was programmed to be initially kept at $45^{\circ} \mathrm{C}$ for $2 \mathrm{~min}$, raised to $7^{\circ} \mathrm{C} / \mathrm{min}$ until it reached $320^{\circ} \mathrm{C}$ and kept for $10 \mathrm{~min}$. Helium was used as a carrier gas, and the detector and the injector were at $340^{\circ} \mathrm{C}$ and $250^{\circ} \mathrm{C}$, respectively.

In addition, the wet gravimetric tar mass was obtained to measure total tar generated in the tar sampling. After filtering through filter paper, $5 \mathrm{~mL}$ of tar solution was removed. The weight of the tar solution remaining after separating with isopropyl alcohol was 
measured by means of the rotary evaporator (Model N-1000-SW, Eyela, Japan).

To determine pore development of the sludge char, a nitrogen adsorption test was conducted. Using nano POROSITY (Model NanoPOROSITY-XQ, Mirae SI, Korea), $\mathrm{N}_{2}$ adsorption ability was measured by taking the isothermal adsorption curve at $-196^{\circ} \mathrm{C}$ [14]. Adsorption characteristics were analyzed, and specific area was calculated using a BET equation. The method for determining pore distribution and average pore size were the HK (Horvath-Kawazoe) and BJH (Barret-Joyner-Halenda) equations for micropore and mezopore, respectively. To compare pore development in the sludge char, SEM (scanning electron microscopy; Model S-4800, Hitachi Co., Japan) was used at 50,000 times of resolution.

For $\mathrm{NH}_{3}$ and $\mathrm{HCN}$ generated from the nitrogen compounds in sludge, boric acid solution ( $0.5 \mathrm{w} / \mathrm{w} \% 50 \mathrm{~mL}$ ) was used to absorb $\mathrm{NH}_{3}$, and sodium hydroxide solution $(0.2 \mathrm{~mol} / \mathrm{L} 20 \mathrm{~mL})$ was used to absorb HCN using an absorption solution in an impinger. Concentrations of $\mathrm{NH}_{3}$ and $\mathrm{HCN}$ were derived using the indophenol method (ES 01303.1) and the pyridine-pyrazolone method (ES 01312.1) [15].

\section{Results and Discussion}

The SCCM byproduct from this experiment was used as an MW receptor for drying-gasification of the dewatered sewage sludge.

Tests were conducted as gasification gas, $\mathrm{CO}_{2}$, was set to reach $25^{\circ} \mathrm{C}$, which is room temperature gas (RTG). To evaluate the impact of temperature of the supplied gas at high temperature gas (HTG) of $250^{\circ} \mathrm{C}$ was supplied to the FBR for comparison, and gasification characteristics were compared. To understand the catalytic effects of the MW receptor, the dried carbonized material impinged with an Fe catalyst in the sludge char (Fe catalyst impingement (FCI)) was used to compare RTG results while $\mathrm{CO}_{2}$ was supplied at room temperature.

The dewatered sewage sludge used in this study contained $82 \%$ moisture (see Table 1). The moisture in sewage sludge is divided into free water, interstitial water, surface water, and bound water [16]. The free water is not associated with solid particles and includes void water not affected by capillary force. The interstitial water is trapped in crevices and interstitial spaces of flocs and organisms. The surface water stays on the surface of solid particles by adsorption and adhesion. The bound water chemically combines by hydration [17]. It is hard to distinguish the free water and the bound water of sewage sludge. The removable moisture by mechanical dewatering is the free water and the interstitial water. The surface water and the bound water are known as irremovable by mechanical dewatering [18].

In HTG for which gasification gas is supplied at high temperature, the bound water described above evaporates relatively faster than the RTG. Therefore, the amount of moisture in the dewatered sludge of which the MW reception is good was reduced to slightly lower than the MW reception. Thus, the initial heating is somewhat late for the case of HTG.

Compared to conventional technology, MW devices can eliminate or severely reduce heat transfer resistances that are common in conventional chemical processes. This is due to the potential of MWs to heat the material directly, given that the transfer of energy occurs through the interaction of the molecules or atoms within the material. Thus, the advantages of MW heating with respect to the conventional process would be a higher heating efficiency and heating rate, and therefore a greater saving of time [19].

\subsection{Gasification Products}

For $\mathrm{CO}_{2}$ gasification treatment of dewatered sewage sludge, different gasification temperatures, and three different catalytic types (RTG, HTG, FCI) were used. The gasification products are shown in Fig. 2.

For the three conditions for sludge gasification, gas, char, and tar were produced the same as in the conventional gasification [12]. Although each amount was slightly different depending on each condition, the gas was the major component followed by sludge char which remains, and tar composed of some heavy hydrocarbons (For RTG, $56.8 \%$ of gas, $4.2 \%$ of tar, and 39\% of char).

In dewatered sludge containing a large amount of moisture, the fixed carbon, and volatile components in the sludge react with the moisture in the sludge in the gasification process as follows. At higher temperature, the reactions can be more active to increase the amount of produced non-condensable lean gas.

$$
\begin{gathered}
\text { Water gas reaction: } \mathrm{C}+\mathrm{H}_{2} \mathrm{O} \leftrightarrow \mathrm{CO}+\mathrm{H}_{2} \\
\qquad \mathrm{H}_{298 \mathrm{~K}}=132 \mathrm{~kJ} \mathrm{~mol}^{-1} \\
\text { Water gas shift reaction: } \mathrm{CO}+\mathrm{H}_{2} \mathrm{O} \leftrightarrow \mathrm{CO}_{2}+\mathrm{H}_{2} \\
\Delta \mathrm{H}_{298 \mathrm{~K}}=-41.5 \mathrm{~kJ} \mathrm{~mol}^{-1} \\
\text { Methane gasification: } \mathrm{CH}_{4}+\mathrm{H}_{2} \mathrm{O} \leftrightarrow \mathrm{CO}+3 \mathrm{H}_{2} \\
\Delta \mathrm{H}_{298 \mathrm{~K}}=206.1 \mathrm{~kJ} \mathrm{~mol}^{-1} \\
\text { Tar steam gasification: Tar }+\mathrm{vH}_{2} \mathrm{O} \rightarrow \mathrm{xCO}+\mathrm{yH}_{2}
\end{gathered}
$$

In the gasification, the produced gas was more of a dominant component in RTG than in HTG. The reason for this is as follows. When the gasification gas at $250^{\circ} \mathrm{C}$, which is higher than the water evaporation temperature, was introduced into the sludge sample bed layer in the FBR, the free water on the surface of sludge (see Fig. 1) evaporated to reduce the water content in the sludge. The water in the sludge is a dielectric that absorbs the MW energy, but reduction of the free water reduced the MW energy in the sludge to relatively reduce the initial heating rate. In addition, the smaller amount of water reduced the amount of non-condensable gas produced due to the aforementioned water. To increase the amount of gas produced in gasification, a higher heating rate and longer duration time at a high temperature $\left(>650^{\circ} \mathrm{C}\right)$ is needed to maximize secondary reaction of Eq. (1)-(4) [20]. More tar and char were produced for HTG than RTG in contrast to the produced gases, and this can be elucidated by the lower heating rate. This contributed to lower evaporation of tar from the sludge sample and less conversion to light non-condensable gases by a secondary reaction in tar steam gasification (Eq. (4)).

MW dielectric heating involves conversion of vibrational kinetic energy to thermal energy after direct transfer of MW energy into the MW receptor. This is unlike the conventional hot air heating method, which is heat transfer from the outside of a receptor. 


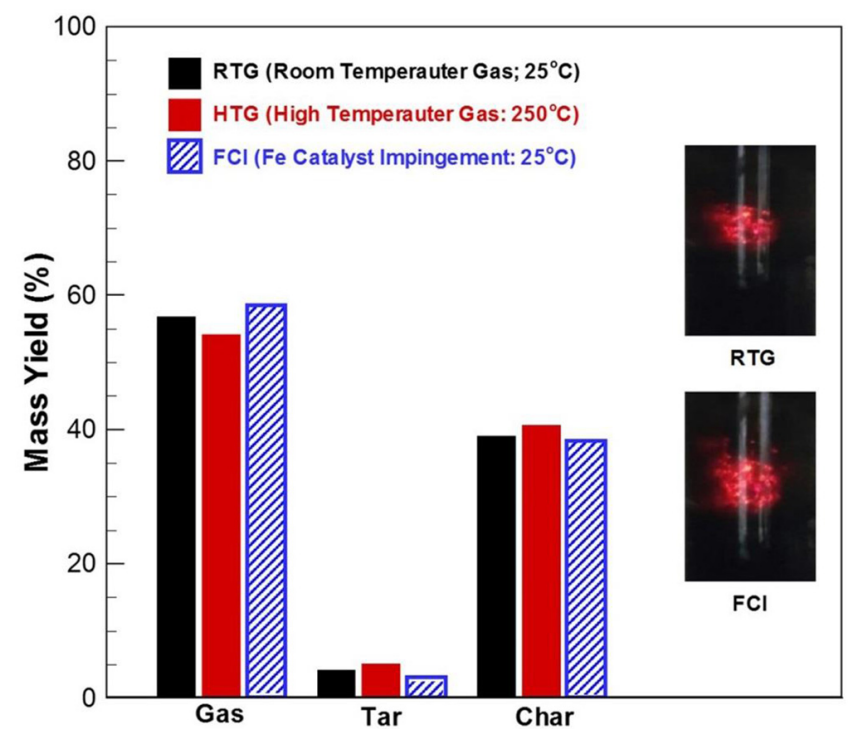

Fig. 2. Mass yield comparison depending on gas feed temperature and catalyst application of the MW receptor; RTG: $25^{\circ} \mathrm{C}$, HTG: $250^{\circ} \mathrm{C}$, and $\mathrm{FCl}: 25^{\circ} \mathrm{C}$.

Therefore, micro-plasma discharge is locally developed in the carbon receptor, which is a dielectric solid, and a specific location of the MW receptor is thus at a higher temperature than the temperature of the sludge sample bed [21].

While the gasification gas was introduced at room temperature in the same condition, RTG using SCCM for the MW receptor was compared with an FCI. The amount of produced gas was increased, and the amount of tar and char was reduced. As shown in Fig. 2, FCI had a greater hot spot and was stronger because of the generated micro-plasma to further activate the primary heterogeneous reaction (Eq. (5)) between the solid and gases, and the secondary homogeneous reaction (see Eq. (1)-(4)) between gases.

$$
\begin{gathered}
\text { Boudouard reaction: } \mathrm{C}+\mathrm{CO}_{2} \leftrightarrow \mathrm{CO} \\
\Delta \mathrm{H}_{298 \mathrm{~K}}=173 \mathrm{~kJ} \mathrm{~mol}^{-1}
\end{gathered}
$$

\subsection{Production Characteristics of Produced Gas}

The major combustible gases from MW drying-gasification of dewatered sludge include hydrogen $\left(\mathrm{H}_{2}\right)$ and $\mathrm{CO}$ along with a small amount of $\mathrm{CH}_{4}$ and hydrocarbons (total hydrocarbons (THCs): $\mathrm{C}_{2} \mathrm{H}_{4}$, $\mathrm{C}_{2} \mathrm{H}_{6}, \mathrm{C}_{3} \mathrm{H}_{8}$ ).

$\mathrm{H}_{2}$, $\mathrm{CO}$, and $\mathrm{CO}_{2}$ were produced by the secondary reactions (Eq. (1)-(4)) between the gas (or tars) around the sludge sample bed layer and all waters from surface water and bound water in the organic cells of the sludge, interstitial water between cells, and free water on the surface of the sludge. $\mathrm{CH}_{4}$ and THCs were mostly from the following methanation reaction Eq. (6) and tar cracking Eq. (7) [12].

$$
\begin{gathered}
\text { Methanation reaction: } \mathrm{CO}+3 \mathrm{H}_{2} \leftrightarrow \mathrm{CH}_{4}+\mathrm{H}_{2} \mathrm{O} \\
\Delta \mathrm{H}_{298 \mathrm{~K}}=-206.1 \mathrm{~kJ} \mathrm{~mol}^{-1}
\end{gathered}
$$

Tar cracking: Tar $\rightarrow \mathrm{wH}_{2}+\mathrm{xCO}+\mathrm{yCO}_{2}+\mathrm{zC}_{\mathrm{n}} \mathrm{H}_{\mathrm{m}}$
In the case of RTG for which $\mathrm{CO}_{2}$ was supplied at room temperature, the concentrations of major produced gases were $20.1 \%$ $\mathrm{H}_{2}$, 38\% CO, $0.7 \% \mathrm{CH}_{4}$, and 9\% THCs. Compared with conventional pyrolysis/steam gasification, the amount of CO was more than $\mathrm{H}_{2}$. This is because gasification has lower activation energy for the Boudouard reaction in gasification than pyrolysis [19]. That is, the lower activation energy in the reaction between carbon in sludge char and $\mathrm{CO}_{2}$ contributed to a higher conversion rate to $\mathrm{CO}$, and some supplied $\mathrm{CO}_{2}$ was consumed. Therefore, $\mathrm{CO}_{2}$ showed a lower concentration than the amount of consumed $\mathrm{CO}_{2}$, resulting in the negative value shown in Fig. 3.

In the case of HTG, the amount of produced $\mathrm{H}_{2}$, CO, and THCs were slightly less than in RTG, and this can be elucidated by the smaller water content in the sludge, which leads to lower MW dielectric heating. This decreased the likelihood of primary and secondary reactions.

The sludge char, carbon receptor, contains metallic components like $\mathrm{Cr}, \mathrm{Cu}, \mathrm{Mn}, \mathrm{Ni}$, and a trace of alkaline earth metals, such as calcium (Ca) and barium (Ba). These metals can be used as catalysts, but a small amount of the metals was included in the sludge char. Therefore, Fe, which is an excellent catalyst [22] for modifying gases and tar, was impregnated into the SCCM (FCI) and then dried to apply the catalyst carbon receptor for the FCI experiment.

FCI showed concentrations of $22.6 \% \mathrm{H}_{2}$ and $41 \% \mathrm{CO}$, more than in RTG. The concentrations of $\mathrm{CH}_{4}$ and THCs were reduced to $0.68 \%$ and $8 \%$, respectively. As described in Fig. 3, the expanded area of micro-plasma and localized hot spots were shown in catalyst impregnation into SCCM rather than no catalyst impregnation. This is because steam reforming, $\mathrm{CO}_{2}$ gasification, tar cracking, etc., were activated, and high temperature reaction time was also increased.

In gasification, the higher heating value from the produced gases was calculated with the heating value of each combustible

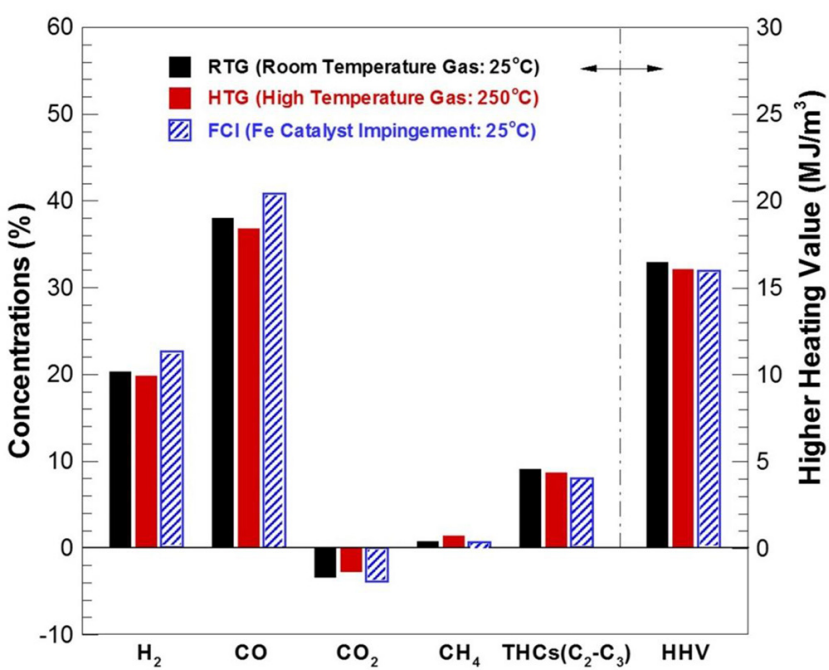

Fig. 3. Comparison of amount of produced gas and heating value. THCS are $\mathrm{C}_{2} \mathrm{H}_{4}, \mathrm{C}_{2} \mathrm{H}_{6}, \mathrm{C}_{3} \mathrm{H}_{8}$ (total non-condensable hydrocarbons); gas concentration does not include supplied $\mathrm{CO}_{2}$. The negative value for $\mathrm{CO}_{2}$ means the amount thereof is less than the supplied amount. 
component of the produced gases and its fraction. The higher heating values were almost the same: $16.48 \mathrm{MJ} / \mathrm{m}^{3}$ for RTG, 16.07 $\mathrm{MJ} / \mathrm{m}^{3}$ for HTG, and $16.07 \mathrm{MJ} / \mathrm{m}^{3}$ for FCI. The reason for the higher heating value for RTG can be elucidated by the greater amount of THCs, incondensable hydrocarbons based on $\mathrm{C}_{2}$ to $\mathrm{C}_{3}$. As a result, although RTG features its higher heating value, FCI with more $\mathrm{H}_{2}$ and CO will be better where RTG is used for fuel cells, chemical processes, etc., which requires better quality produced gases.

\subsection{Generation of Light Tar and Gravimetric Tar}

Fig. 4 shows the concentration of gravimetric tar and light tars as a representative tar like benzene, naphthalene, anthracene and pyrene. The gravimetric tar is total tar, which is a collection of condensable hydrocarbons after evaporation of organic components in the sludge, and each concentration is $538 \mathrm{~g} / \mathrm{m}^{3}$ for RTG, 829 $\mathrm{g} / \mathrm{m}^{3}$ for HTG, and $454 \mathrm{~g} / \mathrm{m}^{3}$ for FCI. The reason for the higher concentration in HTG than in RTG is that there is more tar locally generated by sludge gasification and removed from the bed layer in the non-condensable state, while the hot gasified gases pass through the sludge sample bed layer at $250^{\circ} \mathrm{C}$. Meanwhile, the smaller amount of tar in FCI than in RTG results from the tar generated in the bed layer converted to light tar by means of cracking or tar conversion.

The amount of major light tar for RTG and HTG did not suggest any correlation between them, but HTG showed heavier hydrocarbons like naphthalene and pyrene compared to benzene. This can be elucidated by the reduced water content in the sludge sample bed layer due to early water evaporation. Accordingly, this reduced MW dielectric heating to reduce conversion to light

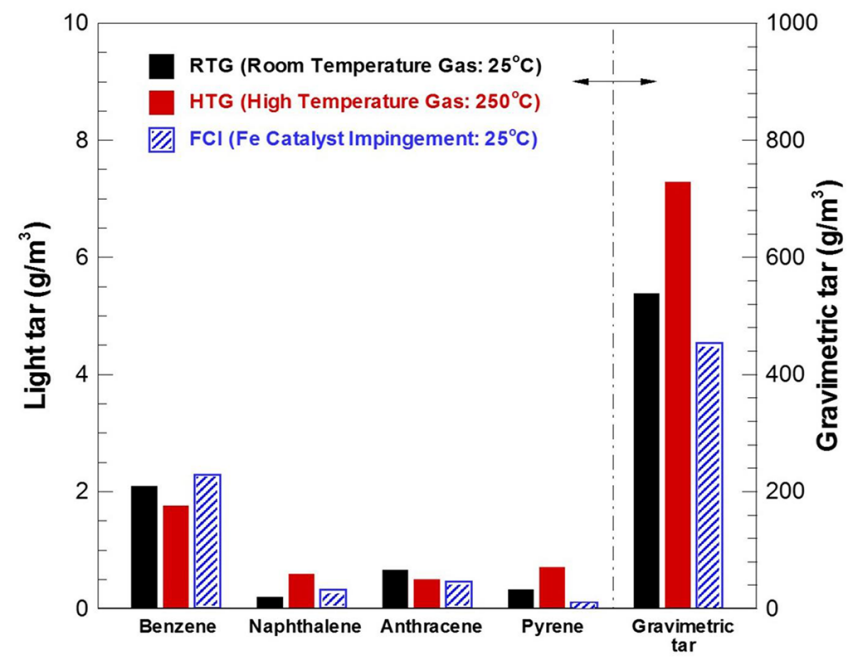

Fig. 4. Comparison for gravimetric and light tars according to each condition. hydrocarbons through tar steam gasification (Eq. (4)) and tar cracking (Eq. (7)). However, light tar showed lower concentrations than gravimetric tar because most tar was converted into gas via tar cracking (Eq. (7)) and tar steam generation (Eq. (4)) while it was in the sludge containing inorganic catalysts. Metallic components (Ca, sodium, potassium, $\mathrm{Fe}$ ) in the sludge facilitate steam, $\mathrm{CO}_{2}$ gasifications, and tar cracking [23].

FCI with Fe catalyst-impregnated and dried SCCM showed a benzene concentration of $2.29 \mathrm{~g} / \mathrm{m}^{3}$, which is larger than that of RTG and HTG. Meanwhile, FCI naphthalene, anthracene, and pyrene concentrations were $0.32 \mathrm{~g} / \mathrm{m}^{3}, 0.46 \mathrm{~g} / \mathrm{m}^{3}$, and $0.11 \mathrm{~g} / \mathrm{m}^{3}$, respectively, lower than those of RTG and HTG. As described for gravimetric tar, FCI involves increased hot spots by micro-plasma discharge to contribute to decomposition of light polycyclic aromatic hydrocarbon $(\mathrm{PAH})$ of naphthalene, anthracene, pyrene into light aromatic tar which is benzene in sequence, via tar cracking.

Light PAH tar has more than two benzene rings, and heavy $\mathrm{PAH}$ is an aromatic hydrocarbon with more than four benzene rings. Tar containing a great amount of condensable tar (light PAH tar) causes issues of gas transfer and equipment damage where it is used as fuel. In the case of using it as an engine fuel, the condensable tar should not be more than $1,027 \mathrm{mg} / \mathrm{m}^{3}$ [12]. However, the light aromatic tar, benzene, is non-condensable tar, but can be used as an energy source and enhances gas heating values unlike the condensable tar described above. As a result, FCI with more benzene and less light PAH can address the concerns described above by using the produced gas containing tar.

\subsection{Characteristics of Sludge Char}

For MW heating $\mathrm{CO}_{2}$ gasification, Table 2 illustrates mean pore size, specific surface area, pore volume, and adsorption amount of sludge char for products of three conditions in RTG, HTG, and FCI. The pore size classification in this study follows the IUPAC classification [24], i.e., micropores $(<20 \AA)$, mesopores (20-500 ̊), and macropores (> $500 \AA$ ).

For RTG and HTG in case of comparison between temperature changes of gasification gas, the porous characteristics and adsorption capacity of the sludge char were not much different. However, FCI with a Fe catalyst in the MW receptor SCCM showed a smaller average pore diameter and larger specific area, pore volume, and adsorption capacity than RTG. This can be elucidated by the increased micro-plasma area and higher reactivity of the catalyst, which contributes to activation of the primary heterogeneous reaction between solid-gas (water gas reaction, Eq. (1)) and the Boudouard reaction (Eq. (5)) for steam gasification.

Generally, the mesopore sludge char produced in this study showed better adsorption capacity for pyrolysis/gasification gas

Table 2. Porous Characteristics and Adsorption Capacity of the Sludge Chars

\begin{tabular}{|c|c|c|c|c|}
\hline Туре & Mean pore size $(\AA ̊)$ & Specific surface area $\left(\mathrm{m}^{2} / \mathrm{g}\right)$ & Pore volume $\left(\mathrm{cm}^{3} / \mathrm{g}\right)$ & Adsorption amount $\left(\mathrm{cm}^{3} / \mathrm{g}\right)$ \\
\hline RTG & 47.43 & 27.38 & 0.089 & 109.72 \\
\hline HTG & 55.65 & 25.52 & 0.064 & 115.37 \\
\hline FCI & 29.19 & 750.57 & 0.133 & 324.47 \\
\hline
\end{tabular}

RTG: $25^{\circ} \mathrm{C}$, HTG: $250^{\circ} \mathrm{C}$, FCI: $25^{\circ} \mathrm{C}$ 

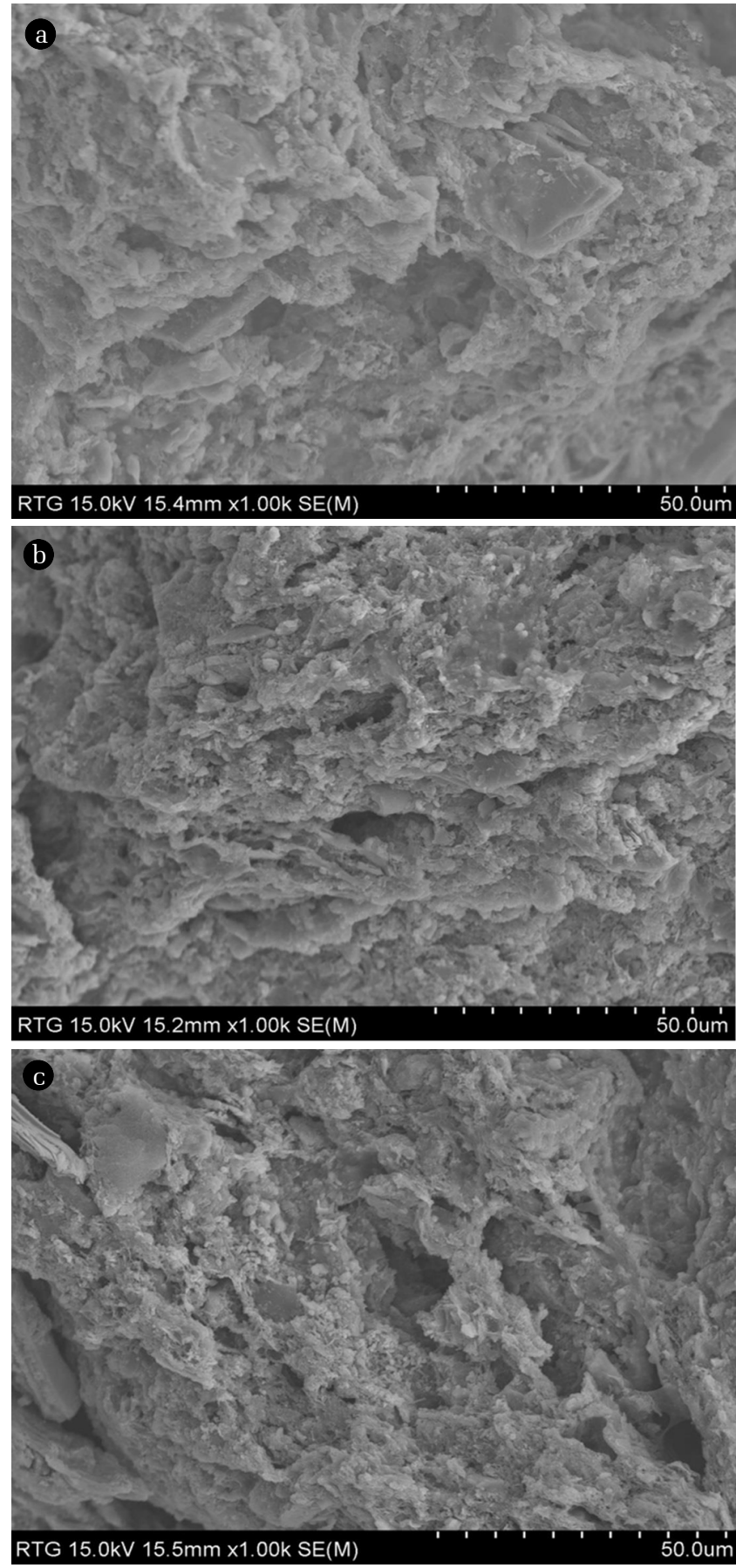

Fig. 5. SEM micrographs of the sludge chars obtained in the MW heating gasification: (a) RTG: $25^{\circ} \mathrm{C}$, (b) $\mathrm{HTG}: 250^{\circ} \mathrm{C}$, (c) $\mathrm{FCl}: 25^{\circ} \mathrm{C}$.

purification where it contained condensable tar [12]. This is because the sludge char does not only have tar but also water introduced in activation. Gas temperature before the produced gas reaches the sludge char was made lower than $30^{\circ} \mathrm{C}$ for condensation, but some moisture in the produced gas is not fully removed and is introduced into the adsorption tower. Because the hydrophilicity surface and mesoporous material favor water adsorption, the sludge char adsorbed a large amount of moisture when compared to the activated carbon and synthetic porous cordierite.

Fig. 5 shows an SEM micrograph of sludge char for the condition of RTG (a), HTG (b), and FCI (c) in MW dielectric heating gasification. Fig. 5(a) shows the case of RTG when the gasification gas was introduced at room temperature. Generally, MW heating involves volumetric heating via absorption of energy into the MW receptor in the sludge. Therefore, surface temperature was not high, and the surface of sludge char is of vitreous-like texture. Any harmful heavy metal is trapped inside.

Fig. 5(b) shows the case of HTG, and internal heating by MW and hot air heating by the hot gasification gas occurred on the sludge surface. This made the heat transferred from the outside to the inside to heat the inside and outside of sludge at the same time. Therefore, partial pores and cracks are seen on the surface of sludge char. Fig. 5(c) shows the case of FCI for which the carbon receptor of Fe catalyst was impinged and dried. The localized hot spots by the micro-plasma discharge contributed to deep cracks or fissures more than RTG and HTG. It was more brittle.

\subsection{Characteristics of $\mathrm{NO}_{\mathrm{x}}$ Precursor}

Among gases produced by gasification of sewage sludge, the nitrogen compounds, $\mathrm{NH}_{3}$ and $\mathrm{HCN}$, are formed, and they are major $\mathrm{NO}_{\mathrm{x}}$ precursors found in the combustion for gas engines, turbines, and burners [22]. In dewatered sewage sludge gasification by MW heating, the amount of $\mathrm{NH}_{3}$ and HCN produced was compared depending on temperature change in the sludge sample bed for different conditions, and the results are shown in Fig. 6.

The gasification was done between $300^{\circ} \mathrm{C}$ and $800^{\circ} \mathrm{C}$. Although the three conditions of RTG, HTG, and FCI differed from each other, a certain amount of $\mathrm{NH}_{3}$ was produced and then increased to reach the peak. After the peak, the amount was reduced again. In the case of $\mathrm{HCN}$, the generated amount increased with bed temperature rise to continue to produce more $\mathrm{HCN}$.

$\mathrm{NH}_{3}$ was formed from thermal decomposition of ammonium absorbed into the nitrogen tars originating from protein type nitrogen in the sludge. The maximum value was found at a bed temperature of $500^{\circ} \mathrm{C}$. After that, $\mathrm{NH}_{3}$ was partially reduced. This is not completely explainable, but the minerals in the sludge are known to act as catalysts for conversion of $\mathrm{NH}_{3}$ into $\mathrm{N}_{2}$ [25]. In particular, this catalyst action was more effective for using an Fe catalyst like FCI, and $\mathrm{NH}_{3}$ was seen reduced at $500^{\circ} \mathrm{C}$, which was a bed temperature lower than the high temperature at $800^{\circ} \mathrm{C}$ for HTG.

In the case of HCN, all three conditions of RTG, HTG, and FCI showed the pattern of increase along with bed temperature rise. However, the formation pattern was different compared with the characteristics of formed $\mathrm{NH}_{3}$ described above in the same bed temperature condition. When bed temperature was lower (e.g., $300^{\circ} \mathrm{C}$ ), a smaller amount of HCN was produced. This is because $\mathrm{HCN}$ was produced mainly from the protein type structure (amino acid or protein) in the sludge, but the amount was not significant. When bed temperature was high (from $500^{\circ} \mathrm{C}$ to $800^{\circ} \mathrm{C}$ ), the amount of $\mathrm{HCN}$ rapidly increased due to thermal cracking of nitrogen-containing tar, which is a primary volatile substance at high temperature. FCI showed relatively more production than RTG and HTG regardless of low or high temperature due to local micro-plasma discharge and catalyst action. 


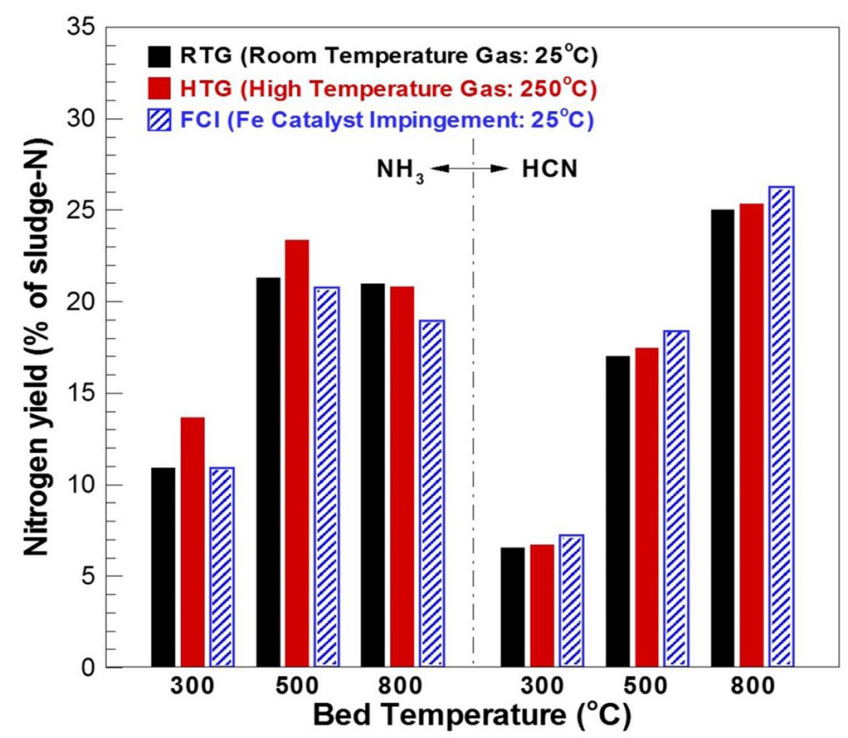

Fig. 6. Characteristics of generated nitrogenous compounds depending on each condition of gasification temperature.

\section{Conclusions}

To examine drying-gasification characteristics of MW dielectric heating of dewatered sewage sludge, lab-scale experiments were conducted. The gasification gas, carbon dioxide, was introduced at RTG and HTG. In addition, the Fe catalyst-impregnated and dried SCCM (FCI) in the MW receptor was used for comparison.

The produced gas was the dominant component, followed by the residue (sludge char) and some tar. In the case of RTG, the produced amount was $56.8 \%$ for gas, $39 \%$ for char, and $4.2 \%$ for tar. As the combustible produced gas, the majority was $\mathrm{H}_{2}$ and CO including some $\mathrm{CH}_{4}$ and hydrocarbons (THCs: $\mathrm{C}_{2} \mathrm{H}_{4}, \mathrm{C}_{2} \mathrm{H}_{6}, \mathrm{C}_{3} \mathrm{H}_{8}$ ). For FCI, the concentration of $\mathrm{H}_{2}$ and $\mathrm{CO}$ was $22.6 \%$ and $41 \%$, respectively. The concentration of $\mathrm{CH}_{4}$ and THCs was $0.68 \%$ and $8 \%$, respectively, and their higher heating value was $16.07 \mathrm{MJ} / \mathrm{m}^{3}$.

For FCI, the generated gravimetric tar was $454 \mathrm{~g} / \mathrm{m}^{3}$, and the major light tar was benzene $\left(2.29 \mathrm{~g} / \mathrm{m}^{3}\right)$. Naphthalene, anthracene, and pyrene showed $0.32 \mathrm{~g} / \mathrm{m}^{3}, 0.46 \mathrm{~g} / \mathrm{m}^{3}$, and $0.11 \mathrm{~g} / \mathrm{m}^{3}$, respectively. As the characteristics of pores and adsorption capacity, the sludge char from FCI showed a smaller average pore diameter, and greater specific area, pore volume, and adsorption capacity. In gasification, $\mathrm{NH}_{3}$ and $\mathrm{HCN}$ were produced as $\mathrm{NO}_{\mathrm{x}}$ precursors, and a given amount of $\mathrm{NH}_{3}$ was generated and then increased to reach the maximum value and then reduced. The amount of generated HCN continually increased along with bed temperature rise.

Based on these results, the gas produced from MW heating gasification of dewatered sludge can be used as a fuel, but it is necessary to treat the gravimetric tar and $\mathrm{NO}_{\mathrm{x}}$ precursor in the gas. Sludge char can be used as a solid fuel or adsorbent.

\section{Acknowledgments}

This work was supported by a National Research Foundation of
Korea (NRF) grant funded by the South Korean government (MSIP) (No. 2015R1A2A2A03003044).

\section{References}

1. Chun YN, Kim SC, Yoshikawa K. Pyrolysis gasification of dried sewage sludge in a combined screw and rotary kiln gasifier. Appl. Energ. 2011;88:1105-1112.

2. Nipattummakul N, Ahmed II, Kerdsuwan S, Gupta AK. Hydrogen and syngas production from sewage sludge via moisture gasification. Int. J. Hydrogen Energ. 2010;35:11738-11745.

3. Fonts I, Kuoppala E, Oasmaa A. Physicochemical properties of product liquid from pyrolysis of sewage sludge. Energ. Fuel. 2009;23:4121-4128.

4. Xie Q, Peng P, Liu S, et al. Fast microwave-assisted pyrolysis of sewage sludge for bio-oil production. Bioresour. Technol. 2014;172:162-168.

5. Beneroso D, Bermudez JM, Aremillas A, Menendez JA. Microwave pyrolysis of microalgae for high sysgas production. Bioresour. Technol. 2013;144:240-246.

6. Zhang J, Tian Y, Zhu J, Zuo W, Yin L. Characterization of nitrogen transformation during microwave-induced pyrolysis of sewage sludge. J. Anal. Appl. Pyrol. 2014;105:335-341.

7. Huang YF, Shih CH, Chiueh PT, Lo SL. Microwave co-pyrolysis of sewage sludge and rice straw. Energy 2015;87:638-644.

8. Motasemi F, Muhammad T, Afzal A. Review on the microwave-assisted pyrolysis technique. Renew. Sust. Energ. Rev. 2013;28:317-330.

9. Chen HF, Namioka T, Yoshikawa K. Characteristics of tar, $\mathrm{NO}_{\mathrm{x}}$ precursors and their absorption performance with different scrubbing solvents during the pyrolysis of sewage sludge. Appl. Energ. 2011;88:5032-5041.

10. Cao JP, Li LY, Morishita K, et al. Nitrogen transformations during fast pyrolysis of sewage sludge. Fuel 2013;104:1-6.

11. Yuan S, Zhou ZJ, Li J, Chen XL, Wang FC. HCN and $\mathrm{NH}_{3}$ (NOx precursors) released under rapid pyrolysis of biomass/coal blends. J. Anal. Appl. Pyrol. 2011;92:463-469.

12. Chun YN. Carbonization-activation of sewage sludge for producing high quality gas and sludge char [dissertation]. Tokyo: Tokyo Institute of Technology; 2012.

13. Damen K, Troost MV, Faaij A, Turkenbury W. $\mathrm{CO}_{2}$ capture and storage. Part A: Review and selection of promising conversion and capture technology. Prog. Energ. Combust. Sci. 2006;32: 215-246.

14. Phuphuakrat T, Namioka T, Yoshikawa K. Tar removal from biomass pyrolysis gas in two-step function of decomposition and adsorption. Appl. Energ. 2010;87:2203-2211.

15. Ábrego J, Arauzo J, Sánchez JL, Gonzalo A, Cordero T, Rodríguez-Mirasol J. Structural changes of sewage sludge char during fixed-bed pyrolysis. Ind. Eng. Chem. Res. 2009;48: 3211-3221.

16. Lee MH, Sin DY, Gang YS. Air pollution testing process method. Xinguang Publisher; 2005. p. 203-349.

17. Vaxelaire J, Cézac P. Moisture distribution in activated sludge: A review. Water Res. 2004;38:2215-2230.

18. Tsang KR, Vesilind PA. Moisture distribution in sludges. Water 
Sci. Technol. 1990;22:135-142.

19. Dominguez A, Fernandez Y, Fidalogo B, Pis JJ, Menendez JA. Bio-syngas production with low concentration of $\mathrm{CO}_{2}$ and $\mathrm{CH}_{4}$ from microwave induced pyrolysis of wet and dried sewage sludge. Chemosphere 2008;70:397-403.

20. Shen L, Zhang DK. An experimental study of oil recovery from sewage sludge by low-temperature pyrolysis in a fluidized bed. Fuel 2003;82:465-472.

21. Zhang XL, Hayward DO, Mingos DMP. Effects of microwave dielectric heating on heterogeneous catalysis. Catal. Lett. 2003;88:33-38.

22. Shen Y, Zhao P, Shao Q, Ma D, Takahashi F, Yoshikawa K. In-situ catalytic conversion of tar using rice husk char-sup- ported nickel-iron catalysts for biomass pyrolysis/gasification. Appl. Catal. B: Environ. 2014;152-153:140-151.

23. Aznar M, Anselmo MS, M-anyà JJ, Murillo MB. Experimental study examining the evolution of nitrogen compounds during the gasification of dried sewage sludge. Energ. Fuel. 2009;23: 3236-3245.

24. Lu GQ. Effect of pre-drying on the pore structure development of sewage sludge during pyrolysis. Environ. Technol. 1995;16: 495-499.

25. Guan R, Li W, Chen H, Li B. The release of nitrogen species during pyrolysis of model chars loaded with different additives. Fuel Sci. Technol. 2004;85:1025-1037. 